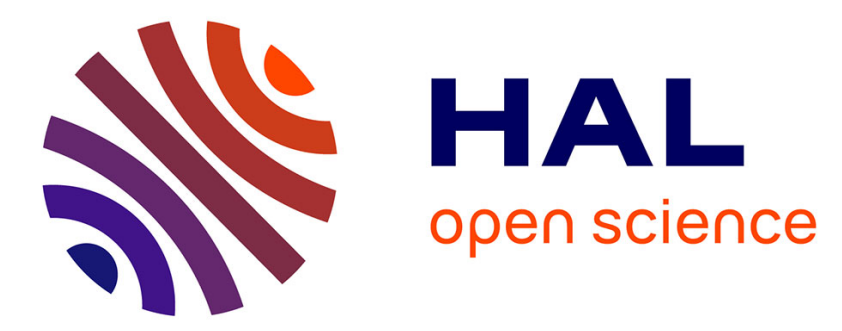

\title{
The Cretan type of nondeletional hereditary persistence of fetal hemoglobin in an Iranian family.
}

Mohammad Hamid, Frouzandeh Mahjoubi, Mohammad Taghi Akbari, Sirous Zeinali, Morteza Karimipoor

\section{- To cite this version:}

Mohammad Hamid, Frouzandeh Mahjoubi, Mohammad Taghi Akbari, Sirous Zeinali, Morteza Karimipoor. The Cretan type of nondeletional hereditary persistence of fetal hemoglobin in an Iranian family.. Annals of Hematology, 2009, 88 (12), pp.1267-8. 10.1007/s00277-009-0756-0 . pasteur-00751227

\section{HAL Id: pasteur-00751227 https://hal-riip.archives-ouvertes.fr/pasteur-00751227}

Submitted on 13 Nov 2012

HAL is a multi-disciplinary open access archive for the deposit and dissemination of scientific research documents, whether they are published or not. The documents may come from teaching and research institutions in France or abroad, or from public or private research centers.
L'archive ouverte pluridisciplinaire HAL, est destinée au dépôt et à la diffusion de documents scientifiques de niveau recherche, publiés ou non, émanant des établissements d'enseignement et de recherche français ou étrangers, des laboratoires publics ou privés. 


\title{
The Cretan type of nondeletional hereditary persistence of fetal hemoglobin in an Iranian family
}

\author{
Mohammad Hamid • Frouzandeh Mahjoubi • \\ Mohammad Taghi Akbari • Sirous Zeinali • \\ Morteza Karimipoor
}

Received: 30 April 2009/Accepted: 8 May 2009/Published online: 26 May 2009

(C) Springer-Verlag 2009

\begin{abstract}
Dear Editor,
The increase of fetal hemoglobin $(\mathrm{HbF})$, in adult life, is mainly due to large deletions within $\beta$-globin cluster in hereditary persistence of fetal hemoglobin (HPFH) and $\delta \beta$ thalassemia or in some cases of nondeletional HPFH (nd$\mathrm{HPFH}$ ) by mutations in promoter region of $\gamma$-globin genes [1-3]. Several nd-HPFH mutations have been reported; most of these mutations occur in transcription factor binding sites, creating new factor binding motifs or disrupting the existing ones [2]. The Cretan type of ndHPFH $(\mathrm{A} \gamma-158 \mathrm{C}>\mathrm{T})$ is characterized by slightly elevated $\mathrm{HbF}$ levels (2.9-5.1\%) and normal hematological indices [4]. This mutation has resulted from two independent gene conversion events $[4,5]$. It is identical to $\mathrm{G} \gamma$-globin gene $X m n \mathrm{I}$ polymorphism $(\mathrm{G} \gamma-158 \mathrm{C}>\mathrm{T})$ which also occurs in healthy individuals.
\end{abstract}

M. Hamid · F. Mahjoubi

Clinical Genetics Department, National Institute of Genetic

Engineering and Biotechnology (NIGEB),

Tehran, Iran

M. Hamid

e-mail: hamid143@yahoo.com

M. Hamid $\cdot$ S. Zeinali $\cdot$ M. Karimipoor $(\bowtie)$

Department of Molecular Medicine,

Biotechnology Research Center, Pasteur Institute of Iran,

Tehran, Iran

e-mail: Mortezakarimi@yahoo.com

M. T. Akbari

Department of Medical Genetics, School of Medical Sciences, Tarbiat Modaras University,

Tehran, Iran
In this study, we report the Cretan type of nd-HPFH for the first time in Iranian families. The family was from Khozestan, south of Iran with Arabic ethnic origin. They were distinguished by slight elevation of $\mathrm{HbF}$ levels and normal hematological indices (Table 1).

After obtaining written informed consent, genomic DNA was extracted from peripheral blood leukocytes using salting out method [6]. The $5^{\prime}$ regulatory regions of the $\mathrm{A} \gamma$ - and $\mathrm{G} \gamma$-globin genes were analyzed by DNA sequencing in three related cases named F.A, K.A, M.A (Fig. 1).

The genotype of $\alpha$ - and $\beta$-thalassemia alleles in studied individuals had been identified previously. It is worth mentioning that no mutation was detected in the $\beta$-globin genes for these cases.

All three cases showed the presence of the $\mathrm{A} \gamma-158 \mathrm{C}>\mathrm{T}$ as a rare mutation (Fig. 1), $\mathrm{A} \gamma-588 \mathrm{G}>\mathrm{A}$ and $\mathrm{G} \gamma-158 \mathrm{C}>\mathrm{T}$ polymorphisms. A $\gamma-158 \mathrm{C}>\mathrm{T}$ mutation is identical to $\mathrm{G} \gamma$ globin gene $X m n I$ polymorphism and creates an additional $X m n I$ restriction site.

As we have shown in Table 1, F.A, K.A, and M.A cases had $\mathrm{C} / \mathrm{T}, \mathrm{T} / \mathrm{T}$, and $\mathrm{C} / \mathrm{T}$ genotypes for $\mathrm{A} \gamma-158 \mathrm{C}>\mathrm{T}$ locus, respectively. The corresponding $\mathrm{HbF}$ levels for these genotypes were $4 \%, 0.2 \%$, and $2.7 \%$. Although F.A and M.A cases had raised $\mathrm{HbF}$ levels correlating with their $\mathrm{C} / \mathrm{T}$ genotypes, K.A with $0.2 \% \mathrm{HbF}$ and $\mathrm{T} / \mathrm{T}$ genotype was unexpected, considering previous studies proposing functional role for $\mathrm{T}$ allele of $\mathrm{A} \gamma-158$ promoter $[4,5]$.

These findings show that the increased $\mathrm{HbF}$ level is not completely under the influences of $\mathrm{T}$ allele. Therefore, our observation from these three related cases showed that probably in addition to $\mathrm{A} \gamma-158 \mathrm{C}>\mathrm{T}$ mutation other factors play a role in expression of $\mathrm{A} \gamma$-globin gene. 
Table 1 Hematological indices of the three adult cases with the Cretan type of nondeletional hereditary persistence of fetal hemoglobin

\begin{tabular}{llll}
\hline $\begin{array}{l}\text { Hematological } \\
\text { index }\end{array}$ & Offspring F.A & Mother K.A & Offspring M.A \\
\hline $\mathrm{Hb}(\mathrm{g} / \mathrm{dl})$ & 12.2 & 14.1 & $?$ \\
$\mathrm{Hct}(\%)$ & 35.7 & 41.5 & $?$ \\
$\mathrm{RBC}(106)$ & 4.08 & 4.7 & $?$ \\
$\mathrm{MCH}(\mathrm{pg})$ & 30.1 & 30.1 & 27.8 \\
$\mathrm{MCV}(\mathrm{fl})$ & 87.5 & 88.5 & 82.6 \\
$\mathrm{HbA} \mathrm{( \% )}$ & 92.8 & 96.5 & 95.3 \\
$\mathrm{Hb}$ A2 (\%) & 3.2 & 3.3 & 2 \\
$\mathrm{HbF}(\%)$ & 4 & 0.2 & 2.7 \\
$\mathrm{G} \gamma-X m n \mathrm{I}$ & $-/+$ & $+/+$ & $+/+$ \\
A $\gamma-158 \mathrm{C}>\mathrm{T}$ & $\mathrm{C} / \mathrm{T}$ & $\mathrm{T} / \mathrm{T}$ & $\mathrm{C} / \mathrm{T}$ \\
Sex/age (years) & $\mathrm{F} / 18$ & $\mathrm{~F} / 45$ & $\mathrm{~F} / 22$ \\
\hline
\end{tabular}

\section{References}

1. Blau CA, Stamatoyannopoulos G (1994) Hemoglobin switching and its clinical implications. Curr Opin Hematol 1:136-142

2. de Vooght KM, van Wijk R, Ploos van Amstel HK, van Solinge WW (2007) Characterization of the $-16 \mathrm{C}>\mathrm{G}$ sequence variation in the promoters of both HBG1 and HBG2: convergent evolution of the human gamma-globin genes. Blood Cells Mol Dis 39:70-74. doi:10.1016/j.bcmd.2007.03.002

3. Katsube T, Fukumaki Y (1995) A role for the distal CCAAT box of the gamma-globin gene in $\mathrm{Hb}$ switching. J Biochem 117:68-76

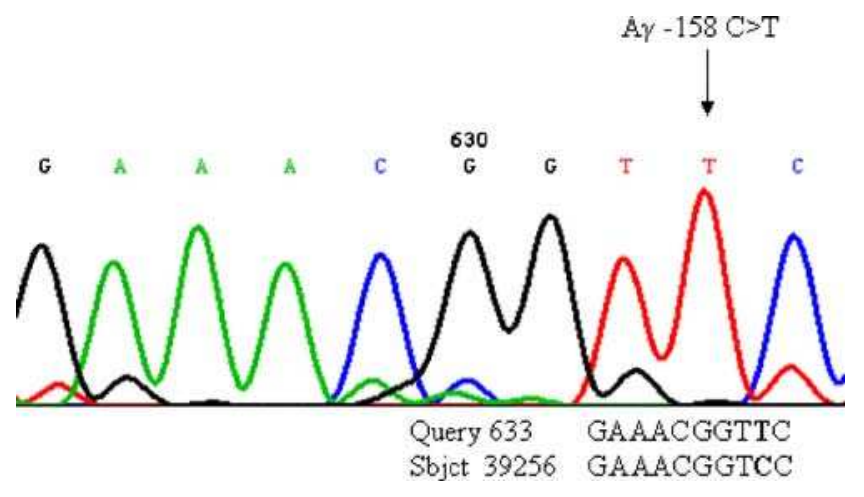

Fig. 1 Sequence analysis showing $\mathrm{A} \gamma-158 \mathrm{C}>\mathrm{T}$ mutation of the $\mathrm{A} \gamma$ globin gene

4. Patrinos GP, Kollia P, Loutradi-Anagnostou A, Loukopoulos D, Papadakis MN (1998) The Cretan type of non-deletional hereditary persistence of fetal hemoglobin [A gamma-158C-->T] results from two independent gene conversion events. Hum Genet 102:629634. doi: $10.1007 / \mathrm{s} 004390050753$

5. Kollia P, Kalamaras A, Chassanidis C et al (2008) Compound heterozygosity for the Cretan type of non-deletional hereditary persistence of fetal hemoglobin and beta-thalassemia or $\mathrm{Hb}$ Sabine confirms the functional role of the A gamma-158 $\mathrm{C}>\mathrm{T}$ mutation in gamma-globin gene transcription. Blood Cells Mol Dis 41:263264. doi:10.1016/j.bcmd.2008.05.009

6. Miller SA, Dykes DD, Polesky HF (1988) A simple salting out procedure for extracting DNA from human nucleated cells. Nucleic Acids Res 16:1215. doi:10.1093/nar/16.3.1215 